\title{
Determinan Penghindaran Pajak Dengan Corporate Social Responsibility Sebagai Variabel Moderasi
}

\author{
Purwoko Erie Dharmawan ${ }^{1}$, Syahril Djaddang ${ }^{2}$, Darmansyah ${ }^{3}$ \\ ${ }^{1.2 .3}$ Universitas Pancasila, Jl. Srengseng Sawah, Jagakarsa, Jakarta Selatan, 12640
}

\section{INFO ARTIKEL}

JEL Classsification:

MH14

H26

H32

Keywords:

tax avoidance, transfer

pricing, corporate social responsibility.

\section{ABSTRACT}

This study aimed to analyze the influence of transfer pricing, thin capitalization, dan tax haven utilization against tax avoidance. This sudy also uses corporate social responsibility as a moderating variable. This study uses secondary data from manufacturing listed company during period of 2014-2016. Samples taken by using purposive sampling method and obtain 189 sampel consist of 63 companies during three years period. The method of testing the data used in this study is panel data regression analysis and descriptive statistics. The result showed that the transfer pricing has significant effect on tax avoidance, while thin capitalization dan tax haven utilization has no significant effect on tax avoidance. Corporate social responsibility has significant influence as moderating between transfer pricing and tax avoidance, but corporate social responsibility has no significant influence as moderating between thin capitalization dan tax haven utilization and tax avoidance.

\section{A B S T R A K}

Penelitian ini bertujuan untuk mengetahui pengaruh transfer pricing, thin capitalization, dan tax haven utilization terhadap penghindaran pajak. Peneltian ini juga menggunakan variabel corporate social responsibility sebagai variabel yang memoderasi pengaruh transfer pricing, thin capitalization, dan tax haven utilization terhadap penghindaran pajak. Studi ini menggunakan data sekunder dari perusahaan manufaktur yang terdaftar di bursa efek indonesia. Pengambilan sampel dilakukan dengan metode purposive samping. Sampel yang diperoleh sebanyak 189 sampel, terdiri dari 63 perusahaan manufaktur selama periode tiga tahun yaitu 2014-2016. Metode analisis yang digunakan dalam mengolah data menggunakan analisis regresi data panel. Hasil penelitian menunjukkan bahwa transfer pricing berpengaruh signifikan terhadap penghindaran pajak, sementara thin capitalization dan tax haven utilization tidak berpengaruh signifikan terhadap penghindaran pajak. Corporate social responsibility dapat memoderasi pengaruh transfer pricing terhadap penghindaran pajak, namun corporate social responsibility tidak dapat memoderasi pengaruh thin capitalization dan tax haven utilization terhadap penghindaran pajak.

*Email Korespondensi: 'erie.dharmawan@gmail.com,2darmansyah155@yahoo.com,3djaddangsyahril@gmail.com 


\section{Pendahuluan}

Praktik penghindaran pajak (tax avoidance) yang terjadi di Indonesia sangat merugikan negara. Berdasarkan data Report of Illicit Financial Flows from the Developing World: 2004 - 2013 yang dirilis oleh Global Financial Integrity (GFI) tahun (2014), Indonesia berada di urutan kesembilan dari negara-negara yang paling dirugikan akibat keluarnya uang yang seharusnya masuk ke kas negara selama periode 2004-2013. Potensi kerugian yang dialami Indonesia selama tahun 2004-2013 diperkirakan sebesar USD180 miliar. Dari jumlah tersebut, $83,4 \%$ berasal dari trade misinvoicing (transaksi yang tidak sesuai bukti), termasuk didalamnya transaksi yang bertujuan untuk menghindari pajak (www.gfintegrity.org).

Salah satu kasus penghindaran pajak yang terjadi di Indonesia adalah kasus pajak PT Toyota Motor Manufacturing Indonesia (PT TMMI) tahun 2007. Direktorat Jenderal Pajak menemukan bahwa PT TMMI menghindari pajak dengan nilai pajak yang kurang dibayar sebesar Rp. 1,22 triliun. Penghindaran pajak dilakukan melalui skema transaksi tertentu yang melibatkan penetapan harga dengan perusahaan afiliasinya atau dikenal dengan transfer pricing. Dalam kasus ini, PT TMMI menjual produk kepada perusahaan afiliasinya Toyota Motor Asia Pacific Pte di Singapura dengan harga yang lebih murah dari Harga Pokok Penjualan. Dengan demikian PT TMMI di Indonesia akan menanggung kerugian untuk setiap penjualan mobil ke Singapura (investigasi.tempo.co).

Kasus penghindaran pajak yang lain dilakukan oleh PT RNI. PT RNI merupakan sebuah perusahaan penanaman modal asing, anak perusahaan dari RMG Ltd di Singapura. Selama bertahun-tahun PT RNI selalu mengalami kerugian. Dilihat dari struktur modalnya, perusahaan ini menggantungkan hidupnya dari hutang afiliasi. Dalam laporan keuangan PT RNI tahun 2014, tercatat utang kepada induknya sebesar Rp. 20,4 miliar. Sementara omzet perusahaan hanya sebesar Rp.
2,178 miliar. PT RNI juga mengakui adanya rugi ditahan pada tahun yang sama senilai $\mathrm{Rp}$. 26,12 miliar (bisniskeuangan.kompas.com). Dengan memberikan utang maka RMG Ltd akan memperoleh imbalan berupa bunga yang tidak dikenakan pajak. Dari sisi PT RNI, bunga tersebut juga dapat dibiayakan (deductible expense). Penghindaran pajak yang dilakukan oleh PT RNI dilakukan dengan menetapkan struktur modal dengan nilai hutang yang tinggi dan modal yang rendah, yang dikenal dengan thin capitalization.

Semakin berkembangnya teknologi informasi dan semakin terbukanya kesempatan transaksi antar negara (cross border transaction) berperan mendorong semakin berkembangnya bisnis dengan berbagai inovasi. Hal tersebut tentu juga akan menciptakan peluang bagi perusahaan untuk menciptakan skemaskema transaksi penghindaran pajak untuk meminimalisasi beban pajaknya. (Darussalam dan Septriadi, 2009). Transaksi-transaksi tersebut memanfaatkan celah karena adanya perbedaan ketentuan dan perbedaan tarif pajak untuk meminimalkan kewajiban pajaknya. Beberapa negara mengenakan pajak dengan tarif yang sangat rendah atau bahkan tidak mengenakan pajak yang dikenal sebagai Tax Haven Country. Perusahaan memanfaatkan adanya Tax Haven Country tersebut dengan berupaya menggeser laba ke negara Tax Haven Country melalui serangkaian skema transaksi yang rumit dengan tujuan untuk menghindari pajak (Desai, 2002). Kasus Google, Amazon, HSBC, Apple, dan Starbucks adalah sebagian contoh skema penghindaran pajak yang melibatkan cross border transaction dengan memanfaatkan adanya Tax Haven Country.

Berbagai penelitian telah dilakukan untuk mengobservasi mengenai faktor-faktor yang mempengaruhi penghindaran pajak. Taylor dan Richardson (2012) yang meneliti penghindaran pajak pada perusahaan yang terdaftar di bursa efek Australia, menemukan bahwa thin capitalization, transfer pricing, income shifting, 
mutinationality, dan tax haven utilization memiliki hubungan signifikan terhadap penghindaran pajak. Hal tersebut senada dengan hasil penelitian Rahayu (2010) yang menyebutkan bahwa skema thin capitalization, tax haven, transfer pricing, controlled firm corporation, dan treaty shopping masih menjadi jalan untuk melakukan penghindaran pajak di Indonesia khususnya oleh Perusahaan Modal Asing (PMA). Penelitian Khomsatun dan Martani (2012) memperkuat temuan Rahayu (2010) serta Taylor dan Richardson (2012) bahwa thin capitalization berpengaruh signifikan terhadap penghindaran pajak.

Meskipun demikian, hasil yang berbeda ditunjukkan oleh penelitian lainnya. Penelitian Tang (2002) sebagaimana dikutip Darussalam et al (2013) membuktikan bahwa hanya sebesar $43 \%$ perusahaan yang melakukan transfer pricing untuk tujuan memaksimalkan laba setelah pajak terkonsolidasi, sedangkan sisanya dilakukan untuk tujuan selain pajak misalnya mengukur kinerja perusahaan dalam grup, memaksimalkan volume penjualan, dan tujuan lainnya. Artinya bahwa transfer pricing tidak semata-mata digunakan untuk penghindaran pajak. Penelitian Belinda (2016) menunjukkan bahwa transaksi antar perusahaan yang memiliki hubungan istimewa tidak berpengaruh signifikan terhadap penghindaran pajak Selanjutnya, penelitian Mayangsari (2015) membuktikan bahwa thin capitalization tidak berpengaruh signifikan terhadap penghindaran pajak. Hal yang sama ditunjukkan oleh hasil penelitian Ismi dan Linda (2016) bahwa thin capitalization tidak memiliki pengaruh yang signifikan terhadap penghindaran pajak.

Lanis dan Richardson (2012) meneliti tentang Corporate Social Reponsibility (CSR), dan menemukan bahwa terdapat hubungan negatif yang signifikan antara pengungkapan CSR dan tindakan agresif untuk menghindari pajak. Menurut Lanis dan Richardson (2012) semakin tinggi tingkat pengungkapan Corporate Social Responsibility maka semakin rendah tindakan agresif untuk menghindari pajak. Hasil penelitian Lanis dan Richardson (2012) sejalan dengan penelitian Huseynov dan Klamm (2012). Fenomena penghindaran pajak merupakan suatu objek penelitian yang menarik, karena berbagai penelitian yang dilakukan seringkali menunjukkan hasil yang berlawanan. Penelitian ini diharapkan dapat memberikan kontribusi mengenai praktik penghindaran pajak yang terjadi di Indonesia.

\section{Telaah Teori dan Pengembangan Hipotesis}

\section{Penghindaran Pajak (tax avoidance)}

Pajak adalah iuran rakyat kepada kas negara berdasarkan undang-undang (yang dapat dipaksakan) dengan tidak mendapat jasajasa timbal (kontra-prestasi), yang langsung dapat ditunjukkan dan yang digunakan untuk membayar pengeluaran umum (Soemitro 1974, dalam Brotodihardjo 2008). Unsur dapat dipaksakan menunjukkan bahwa pajak dapat dipungut dengan paksaan berdasarkan undangundang. Hal tersebut dilakukan karena dalam kenyataannya ada sebagian Wajib Pajak yang tidak memenuhi kewajiban pajaknya. Sebagian besar Wajib Pajak tidak memenuhi kewajiban perpajakannya dengan kesadaran sendiri (tanpa paksaan). Bahkan apabila terdapat peluang pada umumnya Wajib Pajak cenderung meloloskan diri dari pajak (Brotodihardjo, 2008). Tindakan Wajib Pajak tersebut digolongkan sebagai perlawanan terhadap pajak.

Secara umum, tindakan penghindaran diri dari pajak disebut sebagai tax avoidance atau penghindaran pajak, sementara tindakan pengelakan dan melalaikan pajak disebut sebagai tax evasion atau pengelakan pajak. Perbedaan tax avoidance dan tax evasion terdapat pada karakteristik legalitasnya. Penghindaran pajak (tax avoidance) masih dalam koridor hukum sedangkan penggelapan pajak (tax evasion) sudah melanggar hukum dan perundangan yang berlaku (Slemrod 
dan Yitzhaki, 2002). Tax avoidance biasanya diartikan sebagai suatu skema transaksi yang ditujukan untuk meminimalkan beban pajak dengan memanfaatkan kelemahan-kelemahan (loophole) ketentuan perpajakan suatu negara (Darussalam dan Septriadi, 2009). Meskipun hal tersebut legal dan bukan merupakan suatu kecurangan, namun mengakibatkan hasil yang tidak tepat atau sewenang-wenang. (Rohatgi, 2007).

Rohatgi (2007) menjelaskan bahwa praktik penghindaran pajak di dunia umumnya melibatkan skema-skema transaksi transfer pricing, thin capitalization, Controlled Foreign Corporation, dan treaty shopping (Rohatgi, 2007). Sementara Rahayu (2010) menyebutkan bahwa selain skema yang telah dikemukakan oleh Rohatgi (2007) terdapat pula skema penghindaran pajak melalui tax haven utilization.

\section{Transfer Pricing}

Rosenburg (2004) mengungkapkan bahwa "transfer pricing is the price charged by one segment of an organization for a product or service it supplies to another part of the same firm transfer pricing “. Menurut Arnold dan McIntyre (2002), transfer pricing adalah harga yang ditetapkan oleh Wajib Pajak pada saat menjual, membeli, atau membagi sumberdaya dengan afiliasinya. Organization for Economic Cooperation and Development (OECD) (2010) men-definisikan transfer pricing sebagai berikut :"Transfer prices are the prices at which an enterprise transfers physical goods and intangible property or provides services to associated enterprises."

Pengertian transfer pricing merupakan pengertian yang netral, akan tetapi seringkali dikonotasikan sebagai sesuatu yang tidak baik dan bermakna "pejorative" yaitu pengalihan atas penghasilan kena pajak dari suatu perusahaan dalam grup perusahaan multinasional ke perusahaan multinasional lain dalam satu grup yang sama di negara yang tarif pajaknya rendah dalam rangka mengurangi beban pajak. Makna "pejorative" tersebut sebetulnya mengacu pada apa yang disebut sebagai manipulasi transfer pricing, abuse of transfer pricing, transfer mispricing, dan sebagainya (Darussalam et al, 2013).

Pemanfaatan transfer pricing untuk menghindari pajak dapat dilakukan melalui dua cara paling mendasar. Cara pertama, dengan memindahkan penghasilan ke negara yang tarif pajaknya rendah. Cara kedua, dengan memindahkan biaya ke negara yang tarif pajaknya tinggi (Kurniawan, 2015). Transfer pricing berpengaruh terhadap penghindaran pajak. Hasil penelitian Taylor dan Richardson (2012) menunjukkan bahwa transfer pricing berpengaruh signifikan terhadap penghindaran pajak. Penelitian Khomsatun dan Martani (2015) mendukung temuan Taylor dan Richardson (2012). Hal tersebut juga sejalan dengan penelitian Ning Rahayu (2010) yang menemukan bahwa praktik penghindaran pajak sangat umum dilakukan dengan transfer pricing.

\section{Thin Capitalization}

Thin capitalization adalah suatu skema penghindaran pajak dengan cara membuat struktur utang jauh lebih besar dari modal. Skema tersebut muncul akibat adanya aturan ketentuan perpajakan yang membedakan antara perlakuan bunga dengan pengembalian keuntungan (return) atas utang dengan dividen sebagai pengembalian keuntungan atas insvestasi saham (Kurniawan, 2015). Dalam konteks perpajakan, pembayaran bunga merupakan beban yang boleh dibiayakan atau dikurangkan dari penghasilan kena pajak (deductible expense), sedangkan pembayaran dividen bukan merupakan beban yang boleh dibiayakan atau dikurangkan dari penghasilan kena pajak (nondeductible expense). Menurut Rohatgi (2007) thin capitalization merupakan modal terselubung melalui pinjaman yang melampui batas kewajaran. Thin capitalization merupakan upaya untuk mentransformasi 
penghasilan dividen (penghasilan ekuitas), karena terkena pemajakan ganda (laba dan dividen), menjadi penghasilan bunga (penghasilan pinjaman) yang hanya dikenakan pajak sekali.

Thin Capitalization berpengaruh terhadap penghindaran pajak. Hasil penelitian Taylor dan Richardson (2012) menunjukkan bahwa thin capitalization berpengaruh signifikan terhadap penghindaran pajak. Penelitian Khomsatun dan Martani (2015) mendukung temuan Taylor dan Richardson (2012). Hal tersebut juga sejalan dengan penelitian Ning Rahayu (2010) yang menemukan bahwa praktik penghindaran pajak sangat umu dilakukan dengan thin capitalization .

\section{Tax haven utilization}

Spitz (2001) menjelaskan terminologi tax haven mengacu pada yurisdiksi dimana tidak adanya pajak, pajak hanya dikenakan atas transaksi tertentu dan pengenaan tarif yang rendah atas laba yang bersumber dari luar negeri dan atau adanya perlakuan khusus tipe transaksi yang terhutang pajak. Sementara Kurniawan (2015) men-definisikan tax haven country sebagai kebijakan suatu negara yang dengan sengaja memberikan fasilitas pajak, berupa penerapan tarif pajak yang rendah atau bahkan tidak mengenakan pajak sama sekali. Adanya tax haven country merupakan cikal bakal terjadinya praktik-praktik yang tidak sehat di bidang perpajakan internasional (Kurniawan, 2015). Tax haven country memberikan celah dan kesempatan untuk mendapatkan manfaat pajak, yang berasal dari perlakuan perpajakan yang berbeda antar negara. Tax haven utilization berpengaruh terhadap penghindaran pajak. Hasil penelitian Taylor dan Richardson (2012) menunjukkan bahwa tax haven utilization berpengaruh signifikan terhadap penghindaran pajak. Hal tersebut sejalan dengan penelitian Mayangsari (2016) yang menemukan bahwa tax haven utilization berpengaruh terhadap penghindaran pajak.

\section{Corporate Social Responsibility}

Corporate Social Responsibility (CSR) didefinisikan oleh Holme dan Watts (2006) sebagaimana dikutip oleh Lanis dan Richardson (2012) sebagai berikut. "The continuing commitment by business to behave ethically and contribute to economic development while improving the quality of life of the workforce and their family as well as the local community and society at large". Suatu perusahaan dalam dunia nyata merupakan bagian dari sistem sosial yang lebih besar yaitu entitas maupun individu yang ada disekitarnya sebagai stakeholder. Pengungkapan CSR menentukan standar etik perusahaan dalam menyikapi situasi bisnis yang berpengaruh terhadap stakeholder dan masyarakat secara luas. (Lanis dan Richardson, 2012). Standar etik tersebut akan mempengaruhi tindakan perusahaan termasuk tindakan penghindaran pajak dengan berbagai skema, diantaranya transfer pricing, thin capitalization, maupun tax haven utilization. Hasil penelitian (Lanis dan Richardson, 2012) menemukan bahwa pengungkapan CSR berpengaruh signifikan terhadap penghindaran pajak. Hasil penelitian Huseynov dan Klamm (2012) mendukung (Lanis dan Richardson, 2012).

\section{Metode}

Populasi dalam penelitian ini adalah perusahaan-perusahaan manufaktur yang terdaftar di Bursa Efek Indonesia dari selama tahun 2014 sampai dengan 2016. Pengambilan sampel dalam penelitian ini menggunakan teknik purposive sampling. Purposive sampling merupakan teknik pengambilan sampel dengan menggunakan kriteria-kriteria yang telah ditentukan. Adapun kriteria-kriteria penentuan sampel yang digunakan dalam penelitian ini adalah sebagai berikut:

1. Perusahaan yang terdaftar di sektor manufaktur di Bursa Efek Indonesia (BEI) secara konsisten sepanjang tahun 20142016. 
2. Data laporan keuangan serta laporan tahunan (annual report) pada tahun 20142016 telah dimuat dalam website Bursa Efek Indonesia (www.idx.co.id).

3. Memiliki nilai effective tax rate (ETR) antara 0 sampai dengan 1 untuk tahun 20142016.
Berdasarkan kriteria tersebut diperoleh sampel sebanyak 183 sampel yang terdiri dari 183 perusahaan.

Definisi Operasional dan pengukuran yang digunakan dalam penelitian ini diikhtisarkan sebagai berikut.

\section{Tabel 1. Operasionalisasi Variabel}

\begin{tabular}{|c|c|c|c|c|}
\hline No & Variabel & Definisi & Pengukuran & Acuan \\
\hline 1 & $\begin{array}{l}\text { Penghindaran } \\
\text { Pajak/Tax } \\
\text { Avoidance } \\
\text { (ETR) }\end{array}$ & $\begin{array}{l}\text { suatu skema transaksi yang di- } \\
\text { tujukan untuk meminimalkan } \\
\text { beban pajak dengan meman- } \\
\text { faatkan kelemahan-kelemahan } \\
\text { (loophole) ketentuan perpaja-kan } \\
\text { suatu negara }\end{array}$ & ETR $=\frac{\text { Beban Pajak }}{\text { Laba Sebelum Pajak }}$ & $\begin{array}{l}\text { Lanis dan Richardson } \\
\text { (2012), Taylor dan } \\
\text { Richardson (2012), } \\
\text { Guenther (2014), } \\
\text { serta Hanlon dan } \\
\text { Heitzman (2010) }\end{array}$ \\
\hline 2 & $\begin{array}{l}\text { Transfer } \\
\text { pricing }(\mathrm{TP})\end{array}$ & $\begin{array}{l}\text { penentuan harga ketika suatu } \\
\text { perusahaan melakukan transaksi } \\
\text { dengan perusahaan lain yang } \\
\text { merupakan afiliasinya }\end{array}$ & $\begin{array}{l}\text { Transfer Pricing Index } \\
=\frac{\Sigma \text { skor aspek transaksi }}{6}\end{array}$ & $\begin{array}{l}\text { Taylor dan } \\
\text { Richardson (2012), } \\
\text { disesuaikan dengan } \\
\text { ketentuan pajak } \\
\text { Indonesia) }\end{array}$ \\
\hline 3 & $\begin{array}{l}\text { Thin } \\
\text { Capitalization } \\
\text { (DER) }\end{array}$ & $\begin{array}{l}\text { suatu skema penghindaran pajak } \\
\text { dengan cara membuat struktur } \\
\text { utang jauh lebih besar dari modal }\end{array}$ & $\mathrm{DER}=\frac{\text { Hutang }}{\text { Ekuitas }} \times 100 \%$ & $\begin{array}{l}\text { Christiana dan } \\
\text { Martani (2016) }\end{array}$ \\
\hline 4 & $\begin{array}{l}\text { Tax Haven } \\
\text { Utilization } \\
\text { (THav) }\end{array}$ & $\begin{array}{l}\text { penggunaan negara-negara yang } \\
\text { memberikan fasilitas pajak oleh } \\
\text { perusahaan untuk mendapatkan } \\
\text { manfaat/penghematan pajak }\end{array}$ & $\begin{array}{l}\text { skor dummy, apabila perusahaan } \\
\text { memiliki setidaknya satu peru- } \\
\text { sahaan yang memiliki hubungan } \\
\text { istimewa yang berada di negara } \\
\text { tax haven maka diberikan nilai } 1 \text {, } \\
\text { sementara jika perusahaan tidak } \\
\text { memiliki maka diberikan nilai } 0\end{array}$ & $\begin{array}{l}\text { Taylor dan } \\
\text { Richardson (2012) }\end{array}$ \\
\hline 5 & $\begin{array}{l}\text { Corporate } \\
\text { Social } \\
\text { Responsibility } \\
\text { (CSR) }\end{array}$ & $\begin{array}{l}\text { suatu komitmen berkelanjutan } \\
\text { dalam dunia bisnis untuk ber- } \\
\text { tanggung jawab secara ekonomi, } \\
\text { sosial, dan ekologi mencegah } \\
\text { dampak-dampak negatif yang } \\
\text { mungkin terjadi dan untuk } \\
\text { meningkatkan kualitas mas- } \\
\text { yarakat sekitar serta lingkungan } \\
\text { yang menjadi stakeholder } \\
\text { perusahaan. }\end{array}$ & $\begin{array}{l}\text { CSR Disclosure Indexx } \\
=\frac{\Sigma \text { skor pengungkapan CSR }}{52}\end{array}$ & $\begin{array}{l}\text { Lannis dan } \\
\text { Richardson (2012) }\end{array}$ \\
\hline
\end{tabular}

Teknik analisis yang dipakai untuk menjawab permasalahan dan menguji hipotesis yang telah dikemukakan adalah menggunakan teknik analisis regresi data panel dengan menggunakan software Eviews 9. Adapun persamaan regresi dalam penelitian ini dituliskan sebagai berikut. 


$$
E T R=a+b_{1} T P+b_{2} D E R+b_{3} T H a v+b_{4} C S R+b_{5} T P * C S R+b_{6} D E R * C S R+B_{7} T H a v * C S R+e
$$

Keterangan:

$$
\begin{aligned}
& \text { ETR }=\text { Penghindaran Pajak / Tax Avoidance } \\
& \mathrm{A}=\text { Konstanta } \\
& \mathrm{B}=\text { koefisien regresi } \\
& \mathrm{TP}=\text { Transfer Pricing } \\
& \text { DER }=\text { Thin Capitalization } \\
& \text { Thav }=\text { Tax Haven Utilization } \\
& \mathrm{CSR}=\text { Corporate Social Responsibility } \\
& \text { E }=\text { Error }
\end{aligned}
$$

\section{Hasil Penelitian dan Pembahasan}

Tabel 2. Hasil Statistik Deskriptif

\begin{tabular}{lccccc}
\hline Statistik Deskriptif & ETR & TP & DER & THAV & CSR \\
\hline Mean & 0.297979 & 0.454185 & 0.936577 & 0.206349 & 0.409159 \\
Maximum & 0.948000 & 1.000000 & 7.989000 & 1.000000 & 0.769000 \\
Minimum & 0.004000 & 0.000000 & 0.077000 & 0.000000 & 0.135000 \\
Std. Deviation & 0.153842 & 0.245463 & 1.025610 & 0.405759 & 0.152232 \\
\hline
\end{tabular}

Sumber : Hasil Output Data Panel Eviews 9

Pengujian hipotesi diawali dengan penentuan metode estimasi yang paling tepat untuk model regresi data panel. Penentuan metode estimasi dilakukan dengan melakukan tes atau pengujian meliputi Uji Chow (Chow test), Uji Hausman (Hausman Test), dan Uji Lagrange Multiplier (LM Test). Berdasarkan pengujian ketepatan metode estimasi diketahui bahwa metode yang paling tepat adalah dengan model Random Effect. Metode Random Effect berbasis generalized least square (GLS). Menurut Gujarati \& Porter (2009), persamaan yang menggunakan metode Generalized Least Square (GLS) telah memenuhi asumsi klasik sehingga pengujian asumsi klasik tidak diperlukan. Hasil pengujian hipotesis secara lengkap ditampilkan dalam tabel 3.

Tabel 3. Hasil Pengujian

\begin{tabular}{lllll}
\hline Keterangan & B & Std. Error & t-hitung & Sig. \\
\hline TP & -0.497 & 0.154 & -3.211 & 0.016 \\
DER & -0.030 & 0.035 & -0.854 & 0.393 \\
THAV & 0.083 & 0.093 & 0.895 & 0.371 \\
CSR & 0.137 & 0.208 & -1.979 & 0.049 \\
TP*CSR & 0.697 & 0.348 & 1.999 & 0.047 \\
DER*CSR & 0.111 & 0.102 & 1.086 & 0.278 \\
THAV*CSR & -0.063 & 0.205 & -0.310 & 0.756 \\
Constant & 0.531 & 0.084 & 6.263 & 0.000 \\
R-Square & 0.102 & & & \\
Adjusted R-Square & 0.067 & & & \\
F-hitung & 2.941 & & & \\
Sig. F & 0.006 & & & \\
\hline
\end{tabular}

Sumber: Hasil Pengujian 
Berdasarkan hasil pengujian sebagaimana ditampilkan dalam Tabel 3 diketahui bahwa nilai Prob (F-statistic) adalah sebesar 0,006. Angka probabilitas tersebut lebih kecil dari 0,05 sehingga dapat disimpulkan bahwa model yang telah dibuat layak digunakan untuk pengujian hipotesis.

Nilai adjusted $R 2$ adalah sebesar 0,067 atau sebesar 6,7\%. Hal tersebut berarti bahwa 6,74\% variabel Penghindaran Pajak (ETR) dijelaskan oleh variabel independen Transfer Pricing (TP), Thin Capitalization (DER), dan Tax Haven Utilization (THAV); variabel moderasi Corporate Social Responsibility (CSR), serta variabel TP*CSR, DER*CSR, dan THAV*CSR. Sedangkan sisanya sebesar 93,26\% dipegaruhi oleh variabel lain di luar variabel yang diteliti.

\section{Pengaruh Transfer Pricing terhadap Penghindaran Pajak}

Hasil pengujian pada penelitian ini menunjukkan bahwa variabel Transfer Pricing berpengaruh secara signifikan terhadap ETR, dengan arah hubungan negatif. Hal tersebut berarti bahwa semakin banyak atau semakin beragam transaksi Transfer Pricing maka semakin tinggi pula tingkat Penghindaran Pajak. Pengaruh signifikan variabel Transfer Pricing terhadap penghindaran pajak disebabkan karena perusahaan dengan variabel Transfer Pricing yang tinggi melakukan transaksi transfer pricing yang lebih banyak atau beragam daripada perusahaan dengan variabel Transfer Pricing yang rendah. Hal tersebut akan memberikan celah atau kesempatan bagi perusahaan untuk melakukan transaksi yang tidak sesuai kewajaran guna meminimalkan beban pajaknya. Hasil penelitian ini sejalan dengan hasil penelitian Rahayu (2010), Taylor dan Richardson (2011), serta Mayangsari (2016) yang menemukan bahwa transfer pricing berpengaruh signifikan terhadap Tax Avoidance.

Namun hasil penelitian ini tidak sesuai dengan hasil penelitian Belinda (2016) yang meneliti pengaruh transaksi hubungan istimewa terhadap penghindaran pajak. Hasil penelitiannya menunjukkan bahwa transaksi antar perusahaan yang memiliki hubungan istimewa tidak berpengaruh terhadap penghindaran pajak. Perbedaan hasil penelitian tersebut mungkin disebabkan karena perbedaan indikator transaksi hubungan afiliasiyang digunakan. Padapenelitian tersebut Belinda (2016) hanya menggunakan dua transaksi untuk menilai transaksi transfer pricing yaitu transaksi penjualan dan pembelian. Sedangkan dalam penelitian ini digunakan enam indikator untuk menilai transfer pricing sesuai dengan jenis transaksi transfer pricing yang telah diidentifikasikan ketentuan perpajakan di Indonesia. Sementara penelitian Taylor dan Richardson (2012) menggunakan delapan indikator transfer pricing diukur berdasarkan proksi pengukuran kemungkinan ketidakpatuhan melalui transfer pricing yang diadopsi dari ketentuan perpajakan Australia Tax Organization (ATO). Hal tersebut memperkuat simpulan bahwa semakin beragam transaksi transfer pricing yang dilakukan maka akan memberikan celah kemungkinan terjadinya penghindaran pajak.

\section{Pengaruh Thin Capitalization terhadap Penghindaran Pajak}

Hasil pengujian pada penelitian ini menunjukkan bahwa variabel Thin Capitalization (DER) tidak berpengaruh secara signifikan terhadap ETR. Hal tersebut berarti bahwa Thin Capitalization tidak berpengaruh terhadap penghindaran pajak. Hasil penelitian sesuai dengan hasil penelitian Ismi dan Linda (2016) serta Mayangsari (2016).

Namun hasil penelitian ini tidak sesuai dengan hasil penelitian Khomsatun dan Martani (2015) serta Taylor dan Richardson (2011). Perbedaan hasil penelitian ini kemungkinan disebabkan karena perbedaan indikator yang digunakan. Baik Khomsatun dan Martani (2015) maupun Taylor dan Richardson 
(2011) menggunakan variabel dummy untuk menilai Thin Capitalization berdasarkan suatu batasan tertentu. Taylor dan Richardson (2011) menggunakan Maximum Allowable Debt Ratio sesuai ketentuan yang berlaku di Australia, sedangkan Khomsatun dan Martani (2015) menggunakan batasan rasio total utang terhadap total aset sebesar $45 \%$ sesuai ketentuan BAPEPAM untuk perusahaan yang terdaftar dalam Indeks Saham Syariah Indonesia. Dalam penelitian ini digunakan rasio Debt to Equity (DER) untuk memberikan gambaran yang lebih komprehensif. Penggunaan DER untuk meneliti Thin Capitalization juga digunakan dalam penelitian lain, misalnya Christiana dan Martani (2016).

Pengaruh Thin Capitalization yang tidak signifikan terhadap penghindaran pajak dalam penelitian ini kemungkinan disebabkan karena nilai DER pada objek yang diteliti relatif kecil. Berdasarkan statistik deskriptif, nilai ratarata DER pada perusahaan yang diteliti hanya sebesar 0,936. Mayoritas nilai DER berada pada rentang 0 sampai dengan 2. Dari 189 emiten yang menjadi objek penelitian hanya ada 6 emiten yang memiliki nilai DER $>4$. Ditinjau dari sisi ketentuan perpajakan, Peraturan Menteri Keuangan Nomor 169/PMK.010/2015 mengatur bahwa besarnya perbandingan antara utang dan modal ditetapkan paling tinggi sebesar empat dibanding satu (4:1). Berdasarkan ketentuan tersebut dapat diketahui bahwa nilai DER maksimum yang diperbolehkan adalah 4 . Ketentuan tersebut menyiratkan bahwa Otoritas Pajak menentukan bahwa nilai DER yang tidak lebih dari 4 masih dalam batasan wajar karena tidak akan berpengaruh signifikan terhadap kewajiban perpajakan perusahaan. Dengan demikian ketentuan tersebut telah sesuai dengan hasil penelitian ini.

\section{Pengaruh Tax Haven Utilization terhadap Penghindaran Pajak}

Hasil pengujian pada penelitian ini menunjukkan bahwa variabel Tax Haven
Utilization tidak berpengaruh secara signifikan terhadap ETR. Hal ini berarti bahwa Tax Haven Utilization tidak berpengaruh signifkan terhadap penghindaran pajak.

Hasil penelitian ini tidak sesuai dengan hasil penelitian Taylor dan Richardson (2011). Penelitian ini menggunakan indikator yang sama dengan penelitian Taylor dan Richardson (2011) yang melakukan penelitian pada perusahaan terbuka di Australia. Perbedaan hasil penelitian mungkin disebabkan karena terbatasnya data yang diungkapkan oleh perusahaan dalam laporan keuangan. Pada objek yang diteliti, dari 189 objek penelitian hanya terdapat 39 objek saja atau 13 emiten yang terindikasi memanfaatkan negara Tax Haven. Dari 13 perusahaan tersebut, hanya ada empat perusahaan yang mengungkapkan secara jelas nama dan negara tempat perusahaan afiliasi berada. Adapun sisanya, informasi diperoleh dari Off Shore Leaks Database atau data lain dari internet. Hal tersebut dapat disebabkan karena tidak adanya kewajiban untuk mengungkapkan informasi nama dan negara tempat perusahaan afiliasi berada dalam laporan keuangan. Hal yang mungkin berbeda dengan di Australia yang menerapkan kewajiban pengungkapan informasi secara lebih rinci serta melakukan pengawasan terhadap perusahaan dengan lebih ketat.

Dari penelitian atas informasi perusahaan afiliasi yang diungkapkan dalam Laporan Keuangan diketahui bahwa mayoritas perusahaan yang diteliti memiliki hubungan afilasi dengan perusahaan yang berada di Singapura dan Hongkong. Namun demikian, kedua negara tersebut mengenakan pajak badan (Corporate Income Tax) yang relatif rendah. Singapura mengenakan tarif sebesar $17 \%$ sementara Hongkong sebesar $16,5 \%$, lebih rendah dari tarif pajak Indonesia sebesar $25 \%$. Selain itu Singapura dan Hongkong juga memberikan insentif penurunan tarif, serta tidak mengenakan pajak (With Holding Tax) untuk penghasilan tertentu seperti bunga dan dividen (Santosa, 2015). Kebijakan kedua negara tersebut dapat 
meminimalkan beban pajak bagi perusahaan. Terdapat kemungkinan penghindaran pajak yang dilakukan menggunakan skema transaksi melalui kedua negara tersebut, namun kondisi tersebut tidak dapat dilihat dalam penelitian ini karena Singapura dan Hongkong tidak masuk ke dalam daftar negara Tax Haven dari OECD yang digunakan sebagai dasar dalam penelitian ini.

\section{Pengaruh Transfer Pricing terhadap Penghindaran Pajak dengan dimoderasi oleh Corporate Social Responsibility}

Hasil pengujian pada penelitian ini menunjukkan bahwa Corporate Social Responsibility dapat memoderasi pengaruh Transfer Pricing terhadap ETR. Hal ini berarti bahwa Corporate Social Responsibility dapat memoderasi pengaruh Transfer Pricing terhadap penghindaran pajak.

Hasil penelitian Lannis dan Richardson (2012) menemukan adanya hubungan negatif yang signifikan antara pengungkapan CSR dan tindakan pajak agresif. Penelitian Lannis dan Richardson (2012) didukung penelitian Huseynov dan Klamm (2012) yang menemukan pengaruh negatif CSR terhadap penghindaran pajak. Dari kedua penelitian tersebut, dapat disimpulkan bahwa perusahaan yang memiliki pengungkapan CSR yang tinggi maka tingkat penghindaran pajaknya rendah. Pengungkapan CSR merupakan upaya perusahaan untuk memperoleh legitimasi dari masyarakat, begitu pula dengan membayar pajak. Dengan membayar pajak sesuai ketentuan dan tidak melakukan penghindaran pajak maka perusahaan akan memperoleh legitimasi dari masyarakat dan negara.

Pengungkapan CSR menentukan standar etik perusahaan dalam menyikapi situasi bisnis yang berpengaruh terhadap stakeholder dan masyarakat secara luas. (Lanis dan Richardson, 2012). Penghindaran pajak meskipun tidak melanggar aturan namun tidak sesuai dengan semangat hukum dianggap sebagai suatu tindakan yang tidak bertanggungjawab sosial (Avi-Yonah, 2008). Terkait dengan hal tersebut, maka menggunakan skema transfer pricing untuk menghindari pajak merupakan merupakan suatu tindakan yang tidak beretika. Tindakan perusahaan tersebut dapat merusak citra dan reputasi perusahaan di masyarakat dan negara sehingga akan mengganggu legitimasi perusahaan pada lingkup yang lebih luas. Dengan demikan pengungkapan CSR memoderasi pengaruh transfer pricing terhadap penghindaran pajak.

\section{Pengaruh Thin Capitalization terhadap Penghindaran Pajak dengan dimoderasi oleh Corporate Social Responsibility}

Hasil pengujian pada penelitian ini menunjukkan bahwa Corporate Social Responsibility tidak dapat memoderasi pengaruh Thin Capitalization terhadap ETR, yang berarti bahwa Corporate Social Responsibility tidak dapat memoderasi pengaruh Thin Capitalization terhadap penghindaran pajak. Hal tersebut mungkin disebabkan karena data Debt to Equity (DER) Ratio yang digunakan sebagai indikator variabel Thin Capitalization relatif kecil dan memiliki sebaran yang merata. Nilai DER yang relatif kecil tidak memiliki pengaruh signifikan terhadap penghindaran pajak. Oleh karena itu peran moderasi Corporate Social Responsibility atas pengaruh Thin Capitalization terhadap penghindaran pajak juga menjadi tidak signifikan.

HasilpenelitianWahyudi(2015)danHidayah (2017) menunjukkan bahwa aktivitas Corporate Social Responsibility tidak berpengaruh terhadap penghindaran pajak. Wahyudi (2015) menduga penyebab hasil penelitian tersebut karena dua hal, pertama karena mungkin masih rendahnya praktik Corporate Social Responsibility di Indonesia, dan kedua mungkin disebabkan karena sampel yang kurang karena hanya satu tahun pengamatan. Sedangkan Hidayah (2017) menduga hasil yang tidak signifkan tersebut 
disebabkan indikator pengukuran CSR yang kurang spesifik, dan volalitas pengungkapan CSR pada objek penelitian perusahaan konsumsi.

Corporate Social Responsibility yang tidak dapat memoderasi pengaruh Thin Capitalization terhadap penghindaran pajak pada penelitian ini mungkin juga disebabkan karena indikator Corporate Social Responsibility yang belum sepenuhnya mampu menilai Corporate Social Responsibility. Pengukuran Corporate Social Responsibility dalam penelitian ini menggunakan pengukuran Lannis dan Richardson (2012) yang terdiri dari 52 aspek aktivitas CSR individual. Jumlah aspek aktivitas CSR tersebut relatif lebih sedikit dibandingkan dengan pengukuran CSR yang lain misalnya CSR Disclosure Index GRI.3 dengan 78 aspek pengungkapan, atau GRI.4 dengan 90 aspek pengungkapan.

\section{Pengaruh Tax Haven Utilization terhadap Penghindaran Pajak dengan dimoderasi oleh Corporate Social Responsibility}

Hasil pengujian pada penelitian ini menunjukkan bahwa Corporate Social Responsibility tidak dapat memoderasi pengaruh Tax Haven Utilization terhadap ETR, yang berarti bahwa Corporate Social Responsibility tidak dapat memoderasi pengaruh Tax Haven Utilization terhadap penghindaran pajak. Hal tersebut dimungkinkan karena karena terbatasnya data yang perusahaan afiliasi yang diungkapkan oleh perusahaan dalam laporan keuangan. Pada objek yang diteliti, dari 189 objek penelitian hanya terdapat 39 objek saja atau 13 emiten yang terindikasi memanfaatkan negara Tax Haven. Oleh karena itu peran moderasi Corporate Social Responsibility atas pengaruh Tax Haven Utilization terhadap penghindaran pajak juga menjadi tidak signifikan.

Corporate Social Responsibility yang tidak dapat memoderasi pengaruh Tax Haven Utilization terhadap penghindaran pajak pada penelitian ini mungkin juga disebabkan karena indikator Corporate Social Responsibility yang digunakan belum sepenuhnya mampu menilai pengungkapan Corporate Social Responsibility.

\section{Simpulan, Keterbatasan, dan Implikasi Hasil Penelitian}

Transfer pricing berpengaruh signifikan terhadap penghindaran pajak. Hal tersebut disebabkan karena transaksi transfer pricing memberikan celah atau peluang menghindari pajak dengan cara menggeser laba ke perusahaan afiliasi yang berada di negara dengan tarif pajak rendah atau memindahkan biaya ke perusahaan afiliasi yang berada di negara dengan tarif pajak tinggi. Thin Capitalization tidak berpengaruh signifikan terhadap penghindaran pajak. Hal tersebut mungkin disebabkan karena nilai Debt to Equity Ratio (DER) perusahaan yang relatif rendah atau kurang dari 4 tidak memberikan manfaat pajak (tax shield) yang signifikan bagi pajak perusahaan sehingga tidak ada pengaruh signifikan terhadap penghindaran pajak. Sedangkan Tax Haven Utilization tidak berpengaruh signifikan terhadap penghindaran pajak. Hal tersebut mungkin disebabkan karena hanya sedikit perusahaan yang mengungkapkan nama dan negara tempat kedudukan perusahaan afiliasi khususnya yang berada di negara-negara tax haven. Terdapat kemungkinan penghindaran pajak dilakukan melalui pemanfaatan negaranegara yang memiliki tarif pajak lebih rendah namun tidak masuk dalam daftar Tax Haven.

Pengungkapan Corporate Social Responsibility hanya memoderasi pengaruh transfer pricing terhadap penghindaran pajak, tetapi tidak dapat memoderasi pengaruh Thin Capitalization dan Tax Haven Utilization terhadap penghindaran pajak. Hal tersebut mungkin disebabkan karena data yang relatif sedikit, atau karena pengukuran CSR yang kurang menyeluruh.

Penelitian ini belum sepenuhnya memberikan gambaran mengenai penghindaran pajak di Indonesia. Nilai Adjusted $R$ Square sebesar 0,674 relatif kecil sehingga masih banyak faktor yang belum dapat dijelaskan. Oleh karena itu 
penelitian selanjutnya dapat meneliti faktor yang lain misalnya hubungan afiliasi dengan perusahaan di negara-negara yang memiliki tarif pajak rendah. Selain itu penelitian ini hanya mencakup periode penelitian yang terbatas selama 3 tahun serta objek penelitian hanya pada sektor manufaktur, sehingga diharapkan penelitian selanjutnya dapat memperluas periode dan objek penelitian.

Terakhir, penelitian ini juga memiliki keterbatasan pada penilaian yang digunakan khususnya pada pengungkapan Corporate Social Responsibility. Penggunaan pengukuran CSR yang lebih lengkap akan dapat memberikan penilaian CSR secara lebih komprehensif.

\section{Daftar Referensi}

Avi-Yonah, R. S., (2008). Corporate social responsibility and strategic tax behavior. In Tax and corporate governance (pp. 183198). Springer, Berlin Heidelberg.

Belinda, C., (2016). Pengaruh transaksi hubungan istimewa sebagai strategi penghindaran pajak pada perusahaan manufaktur di Bursa Efek Indonesia tahun 2011-2014. Doctoral dissertation, Widya Mandala Catholic University Surabaya.

Brotodihardjo, Santoso, (2010). Pengantar Hukum Pajak. Jakarta: Refika Aditama.

Christiana, Devi \& Dwi Martani, (2016). Determinan Thin Capitalization. Konferensi Regional Akuntansi III (KRA III), Jember.

Darussalam \& Deni Septriadi, (2009). Tax Avoidance, Tax Evasion, Tax Planning, dan Anti Avoidance. Artikel www.ortax.co.id .

Darussalam, D. S., \& Kristiaji, B. B., (2013). Transfer Pricing, Ide, Strategi, dan Panduan Praktis dalam Perspektif Pajak Internasional. Jakarta: Danny Darussalam Tax Center.

Desai, M. A., \& Hines Jr, J. R., (2002). Expectations and expatriations: Tracing the causes and consequences of corporate inversions. National Bureau of Economic Research.
Global Finance Integrity, (2015). Illicit Financial Flows from the Developing World:2004-2013. Global Financial Integrity, Finland.

Guenther, D. A., (2014). Measuring corporate tax avoidance: Effective tax rates and booktax differences. Working paper, University of Oregon.

Gujarati \& Porter. (2009). Dasar-dasar Ekonometrika. Jakarta: Salemba Empat.

Hanlon, M., \& Heitzman, S., (2010). A review of tax research. Journal of Accounting and Economics, 50(2), 127-178.

Hidayah, Nurul, (2017). Pengaruh Pengungkapan Corporate Social Responsibility (CSR) dan Corporate Governance terhadap Praktek Penghindaran Pajak Pada Perusahaan Manufaktur Sektor Barang Konsumsi di Bursa Efek Indonesia 2010-2015. Skripsi, Universitas Muhammadiyah Surakarta.

Huseynov, F., \& Klamm, B. K., (2012). Tax avoidance, tax management and corporate social responsibility. Journal of Corporate Finance, 18(4), 804-827.

Ismi, F., \& Linda, L., (2016). Pengaruh Thin Capitalization, Return On Asset, dan Corporate Governance Pada Perusahaan Jakarta Islami Index (JII). Jurnal Ilmiah Mahasiswa Ekonomi Akuntansi, 1(2), 150165.

Khomsatun, S., \& Martani, D., ( 2015). Pengaruh Thin Capitalization dan Assets Mix perusahaan Indeks Saham Syariah Indonesia (Issi) Terhadap Penghindaran Pajak. Simposium Nasional Akuntansi XVIII, Medan.

Kompas.com, (2016). Terkuak, Modus Penghindaran Pajak Perusahaan Jasa Kesehatan Asal Singapura. http://ekonomi. kompas.com/read/2016/04/06/203829826/ Terkuak.Modus.Penghindaran.Pajak. Perusahaan.Jasa.Kesehatan.Asal. Singapura (diakses 11 November 2016)

Kurniawan, A. M., (2015). Buku pintar transfer pricing untuk kepentingan pajak. 
Yogyakarta, Andi Offset.

Lanis, R., \& Richardson, G., (2012). Corporate social responsibility and tax aggressiveness: An empirical analysis. Journal of Accounting and Public Policy, 31(1), 86108.

Mayangsari, Veronica, (2015). Analisis faktorfaktor yang mempengaruhi penghindaran pajak perusahaan yang terdaftar di Bursa Efek Indonesia. Skripsi, Universitas Diponegoro.

Menteri Keuangan RI. Peraturan Menteri Keuangan Nomor 169/PMK.010/2015 tentang Penentuan Besarnya Perbandingan Antara Utang dan Modal Perusahaan untuk Keperluan Penghitungan Pajak Penghasilan OECD, (2010). OECD Transfer Pricing Guidelines for Multinational Enterprise and Tax Administrasions. Paris: OECD.

Rahayu, N., (2010). Evaluasi Regulasi Atas Praktik Penghindaran Pajak Penanaman Modal Asing. Jurnal Akuntansi dan Keuangan Indonesia, 7(1), 61-78.

Rohatgi, Roy, (2007). Basic International Taxation, Second Edition, Volume II: Practice. New Delhi: Taxmann Allied Services.
Santosa, Anggoro Budi, (2015). Pemagaran Pelarian Pajak Penghasilan. Website Ditjen Pajak Kemenkeu RI. http://www.pajak. go.id/content/article/pemagaran-pelarianpajak-penghasilan (diakses 30 Juli 2017)

Slemrod, J., \& Yitzhaki, S., (2002). Tax avoidance, evasion, and administration. Handbook of public economics, 3, 14231470.

Spitz, B., (2001). International tax havens guide: offshore tax strategies.

Sumitro, R., (1974). Pajak dan pembangunan: kumpulan karangan. Jakarta: Eresco.

Taylor, Grantley, and Grant Richardson, 2012. International corporate tax avoidance practices: evidence from Australian firms. The International Journal of Accounting 47.4 (2012): 469-496.

Tempo.co, (2014). Prahara Pajak Raja Otomotif. https://investigasi.tempo.co/toyota/ (diakses 11 November 2016)

Wahyudi, Dudi, (2015). Analisis Empiris Pengaruh Aktifitas Corporate Social Responsibility(CSR)terhadapPenghindaran Pajak di Indonesia. Proceeding Pertemuan Ilmiah Tahunan Nasional Ke-2 Ikatan Widyaiswara Indonesia. 